\title{
Nursing students: medication use, psychoactive substances and health conditions
}

\author{
Estudantes de enfermagem: uso de medicamentos, substâncias psicoativas e condições de saúde \\ Estudiantes de enfermería: uso de medicamentos, sustancias psicoactivas y condiciones de salud.
}

\author{
Bárbara de Oliveira Prado Sousa \\ ORCID: 0000-0003-0111-9006 \\ André Luiz Thomaz de Souza" \\ ORCID: 0000-0001-5158-9247 \\ Jacqueline de Souza' \\ ORCID: 0000-0002-6094-6012 \\ Sivani Andreia dos Santos" \\ ORCID: 0000-0001-9979-5656 \\ Manoel Antônio dos Santos' \\ ORCID: 0000-0001-8214-7767 \\ Sandra Cristina Pillon' \\ ORCID: 0000-0001-8902-7549
}

'Universidade de São Paulo. Ribeirão Preto, São Paulo, Brazil.

"Centro Universitário do Vale do Ribeira. Registro,

São Paulo, Brazil.

How to cite this article:

Sousa BOP, André LTS, Souza J, Santos SA, Santos MA,

Pillon SC. Nursing students: medication use, psychoactive substances and health conditions.

Rev Bras Enferm. 2020;73(Suppl 1):e20190003. doi: http://dx.doi.org/10.1590/0034-7167-2019-0003

\section{Corresponding author:}

Bárbara de Oliveira Prado Sousa E-mail:barbaraprado89@hotmail.com

EDITOR IN CHIEF: Antonio José de Almeida Filho ASSOCIATE EDITOR: Fátima Helena Espírito Santo

\begin{abstract}
Objective: to assess the use of nonprescription psychoactive medications and their associations with psychoactive substance use and health aspects among nursing students. Method: a crosssectional study conducted with 182 students at a nursing school in the city of Vale do Ribeira, Brazil. Sociodemographic information, screening for alcohol, tobacco and other drug use, information on physical and mental health and physical activity practices were assessed. Results: more than half of the students (79.2\%) used psychoactive drugs without prescription, with a predominance of monthly consumption. Consumption of these drugs was found to be associated with alcohol use, binge drinking, smoking and illicit drug use. Conclusion: the findings have implications for the implementation of health promotion strategies among nursing students, in view of lifestyle changes.

Descriptors: Substance-Related Disorders; Students, Nursing; Health; Drug Utilization; Exercise.
\end{abstract}

\section{RESUMO}

Objetivo: avaliar o uso de medicamentos psicoativos sem prescrição médica e suas associações com o uso de substâncias psicoativas e aspectos de saúde entre estudantes de enfermagem. Método: estudo transversal realizado com 182 estudantes em uma escola de enfermagem localizada no Vale do Ribeira, Brasil. As informações sociodemográficas, triagem do uso álcool, tabaco e de outras drogas, informações sobre saúde física, mental e práticas de atividades físicas foram avaliadas. Resultados: mais da metade dos estudantes $(79,2 \%)$ fizeram uso de medicamentos psicoativos sem prescrição, com predomínio do consumo mensal. Constatouse que o consumo destes medicamentos esteve associado ao uso de álcool, ao binge drinking ao tabagismo e o consumo de drogas ilícitas. Conclusão: esses achados têm implicações para a implementação de estratégias de promoção de saúde junto aos estudantes de enfermagem, tendo em vista mudanças no estilo de vida.

Descritores: Transtornos Relacionados ao Uso de Substâncias; Estudantes de Enfermagem; Saúde; Uso de Medicamentos; Exercício.

\section{RESUMEN}

Objetivo: evaluar el uso de drogas psicoactivas de venta libre y sus asociaciones con el uso de sustancias psicoactivas y aspectos de salud entre estudiantes de enfermeira. Método: estudio transversal realizado con 182 estudiantes en una escuela de enfermería ubicada en Vale do Ribeira, Brasil. Se evaluó información sociodemográfica, detección de consumo de alcohol, tabaco y otras drogas, información sobre salud física y mental y prácticas de actividad física. Resultados: más de la mitad de los estudiantes $(79,2 \%)$ usaban drogas psicoactivas sin receta, con un predominio del consumo mensual. Se descubrió que el consumo de estas drogas estaba asociado con el consumo de alcohol, el consumo excesivo de alcohol, el tabaquismo y el consumo de drogas ilícitas. Conclusión: estos hallazgos tienen implicaciones para la implementación de estrategias de promoción de la salud entre los estudiantes de enfermería en vista de los cambios en el estilo de vida.

Descriptores: Trastornos Relacionados com Sustancias; Estudiantes de Enfermería; Salud; Uso de Medicamentos; Ejercicio.
Submission: 04-11-2018

Approval: 08-04-2019 


\section{INTRODUCTION}

The misuse of psychoactive drugs, such as consumption without assessment and medical indication, has been worrying and increasing in the last decades ${ }^{(1-3)}$, particularly in the young population ${ }^{(4)}$. Substance abuse with sedative, analgesic, anxiolytic, anesthetic or stimulant properties has been classified as an epidemic profile in several countries ${ }^{(5-7)}$. In the university context, these substances are mainly used to enhance the effects of other substances, provide physical and mental changes and increase the concentration period for intellectual activities among students. They are also perceived as socially acceptable compared to illicit drug use ${ }^{(1,5)}$.

Non-medical use of psychoactive drugs is defined as nonprescription, recreational or self-medication use, including the prescribed dosage ${ }^{(8)}$. There is a growing concern among health professionals and managers regarding the explosive growth of this consumption. In 20102.6 million individuals started using psychotropic drugs (tranquilizers, sedatives and stimulants) with an average age of 25,24 and 21 years, respectively ${ }^{(9)}$. This initiation has taken place at an earlier age.

In addition to the use of nonprescription psychoactive drugs $s^{(5)}$, the consumption of tobacco(10), illicit drugs ${ }^{(11)}$ and alcohol ${ }^{(12)}$, especially in binge drinking (BD) ${ }^{(13)}$ among undergraduate students is reported recurrent in the literature. According to data from the First Brazilian National Survey on Alcohol, Tobacco and Other Drug Use (Levantamento Nacional sobre Uso de Álcool, Tabaco e Outras Drogas), more than 18,000 undergraduate students made use of these substances at some point in their lives ${ }^{(14)}$. In addition, one in three undergraduate students have consumed binge drinking alcohol in the past 12 months. There are several negative consequences of this abuse to the health of young people, considering the vulnerability to which they are exposed, as they are still in the stage of physical growth and emotional maturation ${ }^{(14)}$.

This epidemiological picture has motivated educators and health professionals to seek strategies that minimize health problems and strengthen the adoption of a healthy lifestyle ${ }^{(15-17)}$. Within the young population, nursing students are a target audience that has been poorly studied regarding the abuse of alcohol and other psychoactive substances, as well as the use of over-the-counter medications. As it is a social segment exposed to various influences and with an exhaustive routine in the training process, it is considered highly vulnerable to stress. This situation is aggravated by the precariousness of the modes of coping adopted in view of the stressful events experienced in the daily life of academic life, such as the high workload devoted to studies and work ${ }^{(1)}$; the particularities of socialization experiences and peer relationships experienced in the university environment ${ }^{(3)}$; the pursuit of improving the standard of intellectual and academic performance required for professional preparation ${ }^{(1)}$; and the lack and / or insufficiency of involvement in healthy activities and behaviors such as regular exercise and balanced eating ${ }^{(18)}$.

The prevalence of psychoactive medication use without prescription seems to be increasing among young undergraduate students. There is growing evidence about the negative consequences associated with this consumption, which allows characterizing it as a public health problem ${ }^{(3)}$. Students who use over-the-counter psychoactive medications, which are often clandestinely bought or shared by the network of colleagues and friends, mostly also develop problems due to the use of other substances. There is also the consumption of alcohol and other medications ${ }^{(19)}$, involvement in risky sexual behaviors, suicidal thoughts ${ }^{(20)}$, decreased sleep quality ${ }^{(21)}$, in addition to the numerous negative repercussions experienced in all walks of life.

Considering the ease of access to psychoactive substances among undergraduate students, the prevalence of abuse and the potential health risks, the need to investigate these variables in different populations and regions is imminent. The prevalence of psychoactive medication use without prescription in undergraduate students has been recurrently assessed in the scientific context ${ }^{(3,22-23)}$. However, few studies address the problem in nursing students by assessing the relationship with health behaviors and psychoactive substance use.

\section{OBJECTIVE}

To assess the use of nonprescription psychoactive medications and their associations with psychoactive substance use and health aspects among nursing students.

\section{METHODS}

\section{Ethical aspects}

The study was submitted and approved by the Research Ethics Committee of the Union of Teaching and Research Institutions (UNISEPE - Pesquisa da União das Instituições de Ensino e Pesquisa). All stages of the study were performed in accordance with the norms and principles that guide research with human beings established by CNS (Conselho Nacional de Saúde - Brazilian National Health Board) Resolution 466 of December 12, 2012.

\section{Design, period and place of study}

A descriptive survey with a quantitative approach, conducted between August and November 2016, in a private higher education institution based in Vale do Ribeira, São Paulo, Brazil.

\section{Population, sample, inclusion and exclusion criteria}

Considering a total of 261 (100\%) nursing students enrolled in the evening course in 2016, through sample calculation (95\% reliability and $2 \%$ accuracy) the minimum sample required was estimated at 156 students. Students were selected according to the eligibility criteria: being regularly enrolled, 18 years of age or older, and being present in the classroom at the time of data collection. Students who were absent for any reason and those who were absent from the classroom after two attempts to collect data on different days were excluded from the study. Thus, the rate of respondents was $69.7 \%(n=182)$ students.

\section{Study protocol}

Data were collected in the 10 semesters of the nursing course at the end of the period of routine academic activities of the 
institution, by prior appointment and authorization of the teacher, so as not to interfere with class hours. For data collection the tools used were: (1) Sociodemographic and clinical information form; (2) binge or binge drinking ${ }^{(24)}$; (3) Fagerström Test of Nicotine Dependence (FTND) ${ }^{(25)}$; (4) Patient Health Questionnaire $(\mathrm{PHQ} 2)^{(26)}$.

(1) Sociodemographic and clinical information form: presents items related to gender, age group, marital status, year of undergraduate study, with whom you live, experimental use of illicit drugs, chronic illness, current health, frequency of consultation with the doctor, use and frequency of psychoactive medication use without prescription last year (considered the dependent variable), anthropometric measurements, body mass index (BMI) and physical activity. The overall nutritional status was classified from the BMI, estimated based on the cutoff points proposed by the World Health Organization ${ }^{(27)}$, with low weight $\mathrm{BMI}<18.5 \mathrm{~kg} / \mathrm{m}^{2}$, normal weight defined as $\mathrm{BMI}>18.5$ and less than $24.9 \mathrm{~kg} / \mathrm{m}^{2}$, overweight with a BMI of 25 to 29.9 $\mathrm{kg} / \mathrm{m}^{2}$ and obesity with a $\mathrm{BMI} \geq 30 \mathrm{~kg} / \mathrm{m}^{2}$.

(2) Binge drinking: was asked directly about alcohol intoxication, with dichotomous answer (Yes/No). According to the National Institute on Alcohol Abuse and Alcoholism ${ }^{(28)}$, binge is characterized by the consumption of five or more singledose drinks by men, or four or more by women regardless of the frequency of drinking. A Brazilian validation study showed good levels of sensitivity, specificity and accuracy above 0.83 for the assessment of this item through AUDIT-3 ${ }^{(29)}$.

(3) Fagerström Test of Nicotine Dependence (FTND): adapted and validated tool for the Brazilian population, which aims to identify nicotine dependence levels ${ }^{(25)}$. It presents six items related to habits and behaviors related to smoking, and its classification is scored in five levels: 0-2 - very low, 3-4 - low, 5 - medium, 6-7 - high, 8-10 - very high.

(4) Patient Health Questionnaire (PHQ2): this tool consists of two items that assess the frequencies of depressed mood and anhedonia (little interest or pleasure in performing daily activities) in the last two weeks. PHQ2 is a useful tool for screening depressive disorders, especially in health settings $\mathrm{s}^{(30)}$. The purpose of the assessment is not to establish a diagnosis or monitor the severity of depression, but to propose an initial screening. A validation study in Brazil showed good reliability indices, with sensitivity values of 0.83 and specificity of $0.92^{(26)}$. To read the results add up all the answer items. The total score ranges from zero to six points. The final grade comprises 0 to 2 points without symptoms suggestive of depression and above three points with symptoms suggestive of depression.

\section{Analysis of results, and statistics}

Statistical analyzes were performed using the Statistical Package for Social Science (SPSS) version 19.0 (License 10250887). In the data analysis was used descriptive and inferential statistics. The association between psychoactive drug use without prescription and sociodemographic characteristics, alcohol consumption, tobacco use, illicit substances and health conditions were established through the Chi-square test $\left(x^{2}\right)$, with analysis of adjusted residuals for location of values. significant. In all inferential statistical analyzes, $p$ value $<0.05$ was considered as a limit of significance.

For multivariate analysis, the logistic regression model estimated by the Maximum Likelihood Estimation (MLE) Functions was used. The significance of the individual parameter of exploratory variables was assessed using the Wald Chi Square test to assess the use of psychoactive drugs without prescription, the use of other psychoactive substances and health behaviors. For the adjusted model (ORA), we considered the dependent variable (1) use of psychoactive drugs without prescription (categorized with dichotomous answer Yes/No), which was tested with the independent variables that showed significant values in the chi-square test $(p<0.020)$. That is: (a) Alcohol use and (b) binge drinking (AUDIT-C); (c) nicotine dependence (FTND); (d) experimental use of illicit drugs; (e) BMl; (f) frequency of physical activity; (g) physical activity, (h) intense physical exercise for at least 20 minutes a day, twice or more a week; (i) walking or cycling daily. Subsequently, the convergence index model was used, thus obtaining values of $R=0.0752$ and $R 2=0.1173$. For the global null hypothesis test likelihood ratio $X^{2}(5)=14,225, p=$ 0.014 and Wald's test $(5)=12,255$ and $p$ value $=0.031$. Adjusted Odds Ratio (ORA or Exponent (Beta)) and 95\% Confidence Interval (Cl) were considered. The performance of the adjustment model and its predictive power were calculated by the percentage of agreement level (61.3\%) and disagreement (24.4\%), in addition to Somers' D - 0.368, Gamma $=0.430$, Tau values. $-\mathrm{a}=0.122$. These factors adequately explain the model used in the present study.

\section{RESULTS}

Regarding sociodemographic characteristics, most students were female 137 (75.2\%), single 111 (60.9\%), young people with a mean age of $26.7 \pm 8.0$ years, ranging from 17 to 57 years and $45(24.7 \%)$ were enrolled in the fourth year of the course. The consumption of psychoactive medication without prescription was reported by 144 (79.2\%) of the students. Of these, 38 (29.9\%) used it in the last year, 68 (47.4\%) with monthly frequency, 19 (13.2\%) weekly and 14 (9.5\%) daily (data not shown in table). In all the years attended, most students reported psychoactive drug consumption without prescription, with a statistically significant difference (Table 1).

More than half of the students used alcohol in the last 30 days 103 (56.6\%) and 89 (48.9\%) consumed in the binge pattern. Only 11 (6\%) were smokers; of these, 6 (54.5\%) had a mean level of nicotine dependence (FTND) and 19 (10.4\%) had tried some type of illicit drug (data not shown in table). Students who consumed alcohol for the past 30 days in binge drinking, smoking, low nicotine addiction, and illicit drug use were associated with over-the-counter medication (Table 2).

Low rates of illicit substance use were identified last year 19 (10.4\%), with the most commonly used drug being marijuana $15(8.2 \%)$, followed by inhalants $1(1.1 \%)$, hallucinogens 1 (1.1\%) and ecstasy 1 (1.1\%). Regarding the use of psychoactive drugs without prescription among $38(20.8 \%)$ cases there was a predominance of tranquilizers/sedatives 19 (50\%), amphetamines 8 (21\%), anabolic 4 (10.5\%), anticholinergics 5 (13.1\%) and opioids 2 (5.3\%). 
Table 1 - Sociodemographic characteristics of nursing students and relationship of psychoactive drug use without prescription, Registro, São Paulo, Brazil, 2016 ( $n=182)$

\begin{tabular}{|c|c|c|c|}
\hline \multirow[b]{2}{*}{ Variables } & \multicolumn{3}{|c|}{ Medication use $\mathrm{n}(\%)$} \\
\hline & $\begin{array}{c}\text { Yes } \\
144(79.2)\end{array}$ & $\begin{array}{c}\text { No } \\
38(20.8)\end{array}$ & $\underset{p \text { value }}{X^{2}}$ \\
\hline \multicolumn{4}{|l|}{ Gender } \\
\hline Female & $110(80.3)$ & $27(19.7)$ & \multirow{2}{*}{$\begin{array}{c}X^{2}(1)=0.460 \\
p=0.498\end{array}$} \\
\hline Male & $34(75.6)$ & $11(24.4)$ & \\
\hline \multicolumn{4}{|l|}{ Age group } \\
\hline $17-19$ & $26(78.8)$ & $7(21.2)$ & \multirow{4}{*}{$\begin{array}{c}x^{2}(3)=2.738 \\
p=0.434\end{array}$} \\
\hline $20-29$ & 66 (75.9) & $21(24.1)$ & \\
\hline $30-39$ & $41(87.2)$ & $6(12.8)$ & \\
\hline$>40$ years & $11(73.3)$ & $4(26.7)$ & \\
\hline \multicolumn{4}{|l|}{ Marital status } \\
\hline Without a partnet & $88(79.3)$ & $23(20.7)$ & \multirow{2}{*}{$\begin{array}{c}X^{2}(1)=0.004 \\
p=0.948\end{array}$} \\
\hline With a partner & $56(78.9)$ & $15(21.1)$ & \\
\hline \multicolumn{4}{|c|}{ Undergraduate course year } \\
\hline First & 32 (86.5) & $5(13.5)$ & \multirow{5}{*}{$\begin{array}{c}X^{2}(4)=9.927 \\
p=0.042^{*}\end{array}$} \\
\hline Second & $28(65.1)$ & 15 (34.9) & \\
\hline Third & $29(85.3)$ & $5(14.7)$ & \\
\hline Fourth & $39(86.7)$ & $6(13.3)$ & \\
\hline Fifth & $16(69.6)$ & $7(30.4)$ & \\
\hline
\end{tabular}

Note: Chi-square test ( $\chi 2$ ). ${ }^{*} p$ value $<0.05$

Table 2 - Relationship of psychoactive substance use among nursing students and the use of psychoactive drugs without a prescription, Registro, São Paulo, Brazil, 2016 ( $n=182$ )

\begin{tabular}{|c|c|c|c|}
\hline \multirow[b]{2}{*}{ Variables } & \multicolumn{3}{|c|}{ Medication use $\mathbf{n}(\%)$} \\
\hline & $\begin{array}{c}\text { Yes } \\
144(79.2)\end{array}$ & $\begin{array}{c}\text { No } \\
38(20.8)\end{array}$ & $\begin{array}{c}X^{2} \\
p \text { value }\end{array}$ \\
\hline \multicolumn{4}{|l|}{ Alcohol use } \\
\hline No & $70(88.6)$ & $9(11.4)$ & \multirow{2}{*}{$\begin{array}{c}X^{2}(1)=7.605 \\
p=0.006^{*}\end{array}$} \\
\hline Yes & $74(71.8)$ & $29(28.2)$ & \\
\hline \multicolumn{4}{|l|}{ Binge drinking } \\
\hline No & $82(88.2)$ & $11(11.8)$ & \multirow{2}{*}{$\begin{array}{c}X^{2}(1)=9.431 \\
p=0.002^{*}\end{array}$} \\
\hline Yes & $62(69.7)$ & $27(30.3)$ & \\
\hline \multicolumn{4}{|l|}{ Smoking } \\
\hline No & $138(80.7)$ & $33(19.3)$ & \multirow{2}{*}{$\begin{array}{c}X^{2}(1)=4.280 \\
p=0.039^{*}\end{array}$} \\
\hline Yes & $6(54.5)$ & $5(45.5)$ & \\
\hline \multicolumn{4}{|c|}{ Nicotine Dependence (FTND) } \\
\hline Abstentions/ very low & $139(80.8)$ & $33(19.2)$ & \multirow{3}{*}{$\begin{array}{c}X^{2}(2)=7.954 \\
p=0.019^{*}\end{array}$} \\
\hline Low & $3(75.0)$ & $1(25.0)$ & \\
\hline Medium & $2(33.3)$ & $4(66.7)$ & \\
\hline \multicolumn{4}{|c|}{ Experimental use of illicit drugs } \\
\hline No & $134(82.2)$ & $29(17.8)$ & $X^{2}(1)=9.011$ \\
\hline Yes & $10(52.6)$ & $9(47.4)$ & $p=0.003^{*}$ \\
\hline
\end{tabular}

Regarding health problems, 144 (79.2\%) students reported no chronic diseases; half, 93 (51\%), go to a doctor only when ill and $132(72.5 \%)$ have no difficulty sleeping. Regarding perceptions about current health, almost half of the students, 86 (47.2\%), said they had adequate health and the other part reported that they needed improvement, 82 (45\%). In addition, students with BMI within the normal range predominated, 117 (64.3\%), and no symptoms suggestive of depression (PHQ2), 144 (79.1\%) were found. These variables did not differ between the group of students with and without psychoactive medication without prescription (data not shown in table).
Most students expressed interest or pleasure in performing daily activities: 87 (47.8\%) (data not shown in table). Students using psychoactive drugs without prescription differed in relation to BMI. Those who used these drugs were classified as overweight: $22(66.7 \%)$ and obesity $10(58.8 \%)$, as well as showing little interest or pleasure in performing daily activities: 10 (52.6\%), with statistically significant values. The practice of physical activity or sport of any modality, intensity and frequency differed among students taking psychoactive drugs without prescription (Table 3).

Table 3 - Distribution of nursing students according to psychoactive medication use without prescription, health conditions and behavior $(n=182)$, Registro, SP, Brazil, 2016

\begin{tabular}{|c|c|c|c|}
\hline \multirow[b]{2}{*}{ Variables } & \multicolumn{3}{|c|}{ Medication use n (\%) } \\
\hline & $\begin{array}{c}\text { Yes } \\
144(79.2)\end{array}$ & $\begin{array}{c}\text { No } \\
38(20.8)\end{array}$ & $\begin{array}{c}X^{2} \\
p \text { value }\end{array}$ \\
\hline \multicolumn{4}{|l|}{${ }^{* *} \mathrm{BMI}$} \\
\hline$<19.1$ & $11(100.0)$ & - & \multirow{4}{*}{$\begin{array}{c}X^{2}(3)=11.803 \\
p=0.008^{*}\end{array}$} \\
\hline $19.2-27.3$ & $98(83.8)$ & $19(16.2)$ & \\
\hline $27.4-32.3$ & $22(66.7)$ & $11(33.3)$ & \\
\hline$>32.4$ & $10(58.8)$ & $7(41.2)$ & \\
\hline \multicolumn{4}{|c|}{$\begin{array}{l}\text { Little interest or pleasure in } \\
\text { performing daily activities }\end{array}$} \\
\hline None & $73(83.9)$ & $14(16.1)$ & \multirow{4}{*}{$\begin{array}{l}X^{2}(3)=9.576 \\
p=0.023^{*}\end{array}$} \\
\hline Any days & 45 (78.9) & $12(21.1)$ & \\
\hline Half of the days & $16(84.2)$ & $3(15.8)$ & \\
\hline Lmost every day & $10(52.6)$ & $9(47.4)$ & \\
\hline \multicolumn{4}{|c|}{ Physical activity practice } \\
\hline No & 78 (71.6) & $31(28.4)$ & \multirow{2}{*}{$\begin{array}{l}X^{2}(2)=9.405 \\
p=0.002^{*}\end{array}$} \\
\hline Yes & $66(90.4)$ & $7(9.6)$ & \\
\hline \multicolumn{4}{|c|}{ Frequency of physical activity } \\
\hline Not applied & 65 (70.7) & $27(29.3)$ & \multirow{3}{*}{$\begin{array}{l}X^{2}(2)=8.823 \\
p=0.012^{*}\end{array}$} \\
\hline $1-2$ times & $44(84.6)$ & $8(15.4)$ & \\
\hline$\geq 3$ times & $35(92.1)$ & $3(7.9)$ & \\
\hline \multicolumn{4}{|c|}{$\begin{array}{l}\text { Intense exercise for at least } 20 \\
\text { minutes a day. twice or more a week }\end{array}$} \\
\hline No & $67(71.3)$ & $27(28.7)$ & \multirow{2}{*}{$\begin{array}{l}X^{2}(1)=7.241 \\
p=0.007^{*}\end{array}$} \\
\hline Yes & $77(87.5)$ & $11(12.5)$ & \\
\hline \multicolumn{4}{|c|}{ Walking or cycling daily } \\
\hline No & $30(65.2)$ & $16(34.8)$ & \multirow{2}{*}{$\begin{array}{l}X^{2}(3)=7.203 \\
p=0.007^{*}\end{array}$} \\
\hline Yes & $114(83.8)$ & $22(16.2)$ & \\
\hline
\end{tabular}

Table 4 - Multivariate analysis of the relationship between psychoactive drug use without a prescription and the type and frequency of physical activity among nursing students. Registro, São Paulo, Brazil, 2016

\begin{tabular}{|c|c|c|c|}
\hline Variables & $\begin{array}{l}\text { Standard } \\
\text { Error }\end{array}$ & $p$ value & ORA (95\% IC) \\
\hline Intercept & 0.2674 & $<0.0001$ & \\
\hline \multicolumn{4}{|c|}{ Physical activity practice } \\
\hline Yes & 0.4318 & 0.401 & $2.0(0.380-11.213)$ \\
\hline \multicolumn{4}{|c|}{ Frequency of physical activity } \\
\hline 1 - 2 vezes & 0.5777 & 0.604 & $1.7(0.227-12.542)$ \\
\hline$\geq 3$ vezes & 0.3402 & 0.824 & $1.1(0.338-3.971)$ \\
\hline \multicolumn{4}{|c|}{$\begin{array}{l}\text { Intense exercise for at least } 20 \\
\text { minutes a day, twice or more a week }\end{array}$} \\
\hline Yes & 0.2651 & 0.718 & $1.2(0.428-3.421)$ \\
\hline \multicolumn{4}{|c|}{ Walking or cycling daily } \\
\hline Yes & 0.2060 & 0.079 & $2.0(0.920-4.624)$ \\
\hline
\end{tabular}


In multivariate analysis, the use of nonprescription psychoactive drugs was not associated with physical exercise regardless of type and frequency ( $p>0.05)$ (Table 4).

\section{DISCUSSION}

This is one of the few studies conducted in Brazil with nursing students that assessed the use of psychoactive drugs without prescription, analyzing outcomes such as alcohol, tobacco, illicit drugs and health conditions. The findings of this investigation suggest that such use was associated with alcohol and illicit drug use, among other indicators that worsen health conditions. The variety of social and behavioral profiles associated with nonprescription psychoactive drug use among nursing students is reflected in possible health damage and potential interference with academic performance ${ }^{(31-32)}$. For this reason, understanding the patterns of health behaviors can help develop intervention strategies and promote a healthy lifestyle and can alleviate the global burden of disease, especially in the academic environment ${ }^{(33)}$.

Research on behaviors and health styles ${ }^{(10-11)}$ among nursing students has been increased, but studies assessing the abuse of psychoactive drugs without prescription in this population and associated factors are still scarce. This limits the potential for discussion and strategy development for these behaviors. It was found that more than half of the students used psychoactive drugs without prescription in the last year, and this consumption was of monthly prevalence. The reasons given for the prevalence of misuse varied according to age, gender and other factors. However, the major causes include ease of access, misinformation about properties and the perception that they are less harmful than illicit drug use ${ }^{(34)}$.

National studies have assessed non-prescription self-medication and non-abusive use in undergraduate students ${ }^{(23,35)}$. However, the results available for the most part are not specific to nursing students. An American investigation indicated that approximately one in five undergraduate students reported over-the-counter drug abuse at some point in their lives ${ }^{(2)}$. Among the students in this study, the most commonly abused medications were tranquilizers/sedatives and amphetamines. Reporting of anabolic, anticholinergic and opioid use was observed less frequently.

In Brazil, a study conducted with 229 undergraduate and graduate nursing students identified a negative correlation between self-reported sedative use and the degree of student optimism ${ }^{(36)}$. In addition, the same study found that students reported using anxiolytics, stimulants, hallucinogens, and / or hypnotics at some point in their lives, among other psychoactive substances such as alcohol, tobacco, and marijuana. Although there is little specific evidence for nursing students, abuse by young people and especially women has been a common practice ${ }^{(22)}$. Probably, the abuse of tranquilizers / sedatives is motivated by the attempt to reduce the anxiety generated by daily life and improve sleep quality $^{(22)}$. However, these substances have the ability to induce dependence and make the person tolerant, so that the body gradually needs larger doses to achieve the desired effects ${ }^{(34)}$.

Amphetamine abuse has similar effects to cocaine use ${ }^{(37)}$, i.e., these drugs, when used, have the property of causing addiction ${ }^{(34)}$. Amphetamines in the university context are generally used to increase wakefulness, motivation, and cognitive aspects such as learning and memory ${ }^{(34)}$. They can also minimize depressant effects induced by alcohol use, generating euphoria and decreased sense of drunkenness ${ }^{(38)}$ at university parties. In addition, they can be used to reduce appetite in obesity treatment ${ }^{(39)}$.

In the present study, the use of psychoactive drugs without prescription among students differed in relation to the year attended. Students enrolled in all years had a higher prevalence of this use compared to those who did not consume this substance, especially the first, third and fourth year. It is understood that the involvement in this consumption at the beginning of graduation is stimulated by curiosity, improvement in academic performance and ease of access, mainly because they are from the health area. In the final years, it may be associated with stress triggered by graduation, overload of academic work, compulsory internship and, consequently, preparation for insertion in the labor market.

As it was a predominantly female sample, statistically significant differences were expected in relation to gender. The Brazilian survey on the use of psychotropic drugs highlights that the use of anxiolytics is twice as high in women and amphetamine four times as compared to men ${ }^{(40)}$. In addition, the National Institute on Drug Abuse (NIDA) indicates that women take over-the-counter psychoactive drugs in quantities and frequencies higher than men $^{(34)}$, a trend not confirmed in this study. Another relevant result is that the use of psychoactive drugs without prescription was prevalent among students who consumed alcoholic beverages in the last 30 days, in binge, with low level of nicotine dependence and, in addition, made experimental use of illicit drugs. In multivariate analysis, illicit drug use and binge were not confirmed as associated with increased odds among drug abusers.

Safety in the use of prescription drugs in combination with other substances is related to and depends on a number of factors, including drug types, strengths, concomitant use with other substances (e.g., alcohol, tobacco and other drugs) and individual health factors ${ }^{(34)}$. Alcohol consumption and binge drinking can often influence the adoption of behaviors that are often not beneficial to health, such as nicotine consumption, physical inactivity, overweight and abuse of other psychoactive substances ${ }^{(41)}$.

The association between BD and the use of nonprescription psychoactive drugs identified in this study can be explained by the fact that many medications, when misused, interact with the effects of alcohol and / or trigger similar events to other drug use ${ }^{(4)}$. With regard to illicit drug use and psychoactive drug abuse, it is suggested that this use may be associated with the fact that many drugs and / or medications have similar effects. However, social acceptance of drug abuse is greater.

The consumption of these drugs may be linked to the fact that in many situations students and/or health professionals are knowledgeable, have access to information and establish a direct relationship with the drugs in academic and professional daily life ${ }^{(42)}$. The use of tranquilizers/sedatives was identified in half of reports of drug abuse. In this context, it is necessary to reflect and intervene, since the abuse of these drugs represents a potential factor that can be aggravating to health.

Regardless of the type of psychoactive medication taken (tranquilizers/sedatives and amphetamines), these substances cause adverse effects by contributing to the development of tolerance, dependence and withdrawal(43). Such a long-term situation can 
result in significant health damage, impacting the professional, personal and social lives of nursing students. Future nurses should be encouraged to engage in healthy self-care behaviors so that they can encourage the community in which they operate.

Another noteworthy result is the issue of body weight (overweight and obesity) among students using over-the-counter medications. They had altered BMI, considered overweight, sedentary lifestyle and anhedonia symptoms. The academic routine of the nursing course is often marked by an exhaustive workload of theoretical / practical classes and internships. It should be noted that the students investigated come from a course that works at night and that more than half work during the day. Little time is spent for self-care, as a dedication to leisure activities, sports and attention to one's physical and mental health, essential for the pursuit of well-being. Thus, students often choose to consume quick meals based on high-calorie, multi-processed foods, stop exercising ${ }^{(43-44)}$, and abuse medications ${ }^{(2)}$ to optimize academic performance.

As observed in the multivariate analysis, the practice of physical exercise was not related to the increased chances of using nonprescription drugs. There are other factors that should be explored, such as eating habits, academic routine and the practice of social recreation activities. The university environment is a privileged space for the implementation of programs that favor changes in habits and other significant changes in students' lives $^{(45)}$. Thus, the adoption of new habits during the academic course can have lifelong repercussions, whether healthy or not ${ }^{(44)}$.

In a study conducted with undergraduate students from the Northeast region of Brazil, it was found that a significant portion of the students did not adopt healthy living standards related to eating habits, physical exercise, smoking and alcohol consumption $^{(46)}$. These are considered factors directly associated with chronic noncommunicable diseases. In this context, it is important to highlight that the Brazilian National Curriculum Guidelines (Diretrizes Curriculares Nacionais) of the nursing course determine that "nurses must be competent in taking care of their own physical and mental health and seek their well-being as citizens"(47). It is necessary for human resources institutions to offer conditions conducive to the practice of healthy living habits and to provide tools that encourage the acceptance of self-image, the development of problem-solving skills and the regular practice of physical activity.

\section{Study limitations}

The results of the present study should be carefully assessed, as they involve the assessment of a peculiar sample of nursing students from a Brazilian region, which may not reflect the reality of other students. Moreover, as they are students of the evening course, they constitute a different profile of the reality of students from public universities. Most are older workers, while much of the research conducted with Brazilian undergraduate students comes from full-time students and/or from public universities.

\section{Contributions to nursing, health or public policy}

The results have some implications for clinical practice regarding the role of educational institutions in investigating and intervening early in the health indicators of nursing students. Assessing the context of use, expectations for over-the-counter medication use and health behaviors among students can be better appreciated with more robust samples and longitudinal studies. Moreover, it is important to deepen the questions related to signs and symptoms suggestive of depression in future studies, since in this investigation the hypothesis of association with drug abuse was partially confirmed.

\section{CONCLUSION}

Drug abuse without prescription was associated with binge drinking, as well as illicit drug use and nicotine dependence among nursing students. In this group, there was also impairment in physical exercise and body weight above the ideal. In order to reduce the impacts of problems associated with over-the-counter medication use among nursing students, the results of this study can be used for the planning and implementation of actions aimed at healthy lifestyle and damage prevention in higher education institutions. In this case, it is important to consider the economic, cultural and social aspects that permeate the different regions of Brazil.

\section{REFERENCES}

1. Maier LJ, Schaub MP. The use of prescription drugs and drugs of abuse for neuroenhancement in Europe: Not widespread but a reality. Eur Psychol [Internet]. 2015 [cited 2017 Nov 17];20(3):155-66. Available from: http://psycnet.apa.org/buy/2015-04438-001

2. McCabe SE, West BT, Teter CJ, Boyd CJ. Trends in medical use, diversion, and nonmedical use of prescription medications among college students from 2003 to 2013: connecting the dots. Addict Behav [Internet]. 2014 [cited 2018 Dec 06];39(7):1176-82. Available from: https:// www.sciencedirect.com/science/article/abs/pii/S0306460314000732

3. Parks KA, Levonyan-Radloff K, Przybyla SM, Darrow S, Muraven M, Hequembourg A. University student perceptions about the motives for and consequences of nonmedical use of prescription drugs (NMUPD). J Am Coll Health [Internet]. 2017 [cited 2018 Nov 26];65(7):457-65: Available from: https://www.tandfonline.com/doi/abs/10.1080/07448481.2017.1341895

4. Benotsch EG, Koester S, Martin AM, Cejka A, Luckman D, Jeffers AJ. Intentional misuse of over-the-counter medications, mental health, and polysubstance use in young adults. J Community Health [Internet]. 2014 [cited 2018 Nov 12];39(4):688-95. Available from: https://link. springer.com/article/10.1007/s10900-013-9811-9

5. Hernandez SH, Nelson LS. Prescription drug abuse: insight into the epidemic. Clin Pharmacol Ther [Internet]. 2010 [cited 2018 Dec 05];88(3):307-17. Available from: http://onlinelibrary.wiley.com/doi/10.1038/clpt.2010.154/full 
6. Kovatsi L, Tsoukali H, Psaroulis D. New trends in drug abuse coming from USA. AUMJ [Internet], 2017 [cited 2018 Dec 1];35(2):33-36. Available from: https://ejournals.lib.auth.gr/aumj/article/view/5332/5225

7. Fingleton NA, Watson MC, Duncan EM, Matheson C. Non-prescription medicine misuse, abuse and dependence: a cross-sectional survey of the UK general population. J Public Health [Internet]. 2016 [cited 2018 Dec 04];38(4):722-30. Available from: https://doi.org/10.1093/pubmed/fdv204

8. Substance Abuse and Mental Health Services Administration (SAMHSA). Illicit drug use among older adults. Center for Behavioral Health Statistics and Quality, U.S. Department of Health and Human Services; 2009. Available from: http:/www.oas.samhsa. gov/2k9/168/168OlderAdults.htm.

9. Substance Abuse and Mental Health Services Administration (SAMHSA). Results from the 2010 national survey on drug use and health: Summary of National Findings. Center for Behavioral Health Statistics and Quality, U.S. Department of Health and Human Services; 2011. Available from: http://www.samhsa.gov/data/NSDUH/2k10NSDUH/2k10Results.htm\#2.7.

10. Guerra FMRM, Costa CKF, Bertolini SMMG, Marcon SS, Parré JL. Tobacco consumption among college students: a systematic review. Rev Pesqui: Cuid Fundam[Internet]. 2017 [cited 2018 Dec 04];9(2):558-65. Available from: https://www.ssoar.info/ssoar/handle/document/53541

11. Boulton MA, O'Connell KA. Past year substance use by student nurses. J Addict Nurs [Internet]. 2017 [cited 2018 Dec 08];28(4):179-87. Available from: https://journals.Iww.com/jan/Abstract/2017/10000/Past_Year_Substance_Use_by_Student_Nurses.3.aspx

12. Abbasi-Ghahramanloo A, Fotouhi A, Zeraati H, Rahimi-Movaghar A. Prescription drugs, alcohol, and illicit substance use and their correlations among medical sciences students in Iran. Int J High Risk Behav Addict [Internet]. 2015 [cited 2018 Dec 02];4(1):e21945. Available from: https://www.ncbi.nlm.nih.gov/pmc/articles/PMC4360541/pdf/ijhrba-04-01-21945.pdf

13. Hoffman EW, Austin EW, Pinkleton BE, Austin BW. An exploration of the associations of alcohol-related social media use and message interpretation outcomes to problem drinking among college students. Health Commun [Internet]. 2017 [cited 2018 Dec 07];32(7):864-871. Available from: https://www.tandfonline.com/doi/abs/10.1080/10410236.2016.1195677

14. Presidência da República. Secretaria Nacional de Políticas sobre Drogas (BR). I Levantamento Nacional sobre o Uso de Álcool, Tabaco e Outras Drogas entre Universitários das 27 Capitais Brasileiras: Secretaria Nacional de Políticas sobre Drogas[Internet]. 2010 [cited 2017 Dec 1]. Available from: http://www.grea.org.br/userfiles/GREA-ILevantamentoNacionalUniversitarios.pdf

15. Sakae TM, Dambrowski K, Remor KVT. Prevalência do uso de substâncias psicoativas em estudantes dos cursos da área da saúde em uma universidade privada do sul do brasil. Arq Catarin Med [Internet]. 2017 [cited 2018 Nov 15];46(4):140-53. Available from: http://www.acm. org.br/acm/seer/index.php/arquivos/article/view/305

16. Ferraz L, Rebelatto SL, Schneider GC, Anzolin, V. The use of alcohol and tobacco among students of a university in Southern Brazil. Rev Bras Promoç Saúde [Internet]. 2017 [cited 2018 Dec 02];30(1):79-85. Available from: http://www.redalyc.org/html/408/40851313011/

17. Benz MB, DiBello AM, Balestrieri SG, Miller MB, Merrill JE, Lowery AD, Carey KB. Off-campus residence as a risk factor for heavy drinking among college students. Subst Use Misuse [Internet]. 2017 [cited 2018 Dec 06];52(9):1236-41. Available from: https://www.tandfonline.com/ doi/abs/10.1080/10826084.2017.1298620

18. Maia DAM, Marques RB, Maia-Filho ALM. Consumo de bebidas alcoólicas e a prática do binge drinking em acadêmicos de medicina. $\mathrm{R}$ Interd [Internet]. 2017 [cited 2018 Nov 26];10(1):139-146. Available from: https://revistainterdisciplinar.uninovafapi.edu.br/index.php/revinter/ article/view/1068

19. McCabe SE, Teter CJ. Drug use related problems among nonmedical users of prescription stimulants: A web-based survey of college students from a Midwestern university. Drug Alcohol Depend [Internet]. 2017 [cited 2018 Nov 25];91(1):69-76. Available from: http://www. drugandalcoholdependence.com/article/S0376-8716(07)00212-8/abstract

20. Zullig KJ, Divin AL. The association between non-medical prescription drug use, depressive symptoms, and suicidality among college students. Addict Behav [Internet]. 2012 [cited 2018 Dec 09];37(8):890-99. Available from: https://www.sciencedirect.com/science/article/ abs/pii/S0306460312000615

21. Clegg-Kraynok MM, McBean AL, Montogomery-Downs HE. Sleep quality and characteristics of college students who use prescription psychostimulants nonmedically. Sleep Med [Internet]. 2011 [cited 2018 Dec 06];12(6):598-602. Available from: http://www.sleep-journal. com/article/S1389-9457(11)00148-1/abstract

22. Bennett T, Holloway K. Motives for illicit prescription drug use among university students: a systematic review and meta-analysis. Int J Drug Policy [Internet]. 2017 [cited 2018 Dec 11];44:12-22. Available from: https://www.ncbi.nlm.nih.gov/pubmed/28343063

23. Souza MA, Hoeller B, Goetz ER. Estudo comparativo da automedicação praticada por estudantes dos cursos das áreas de Ciências da Saúde, Humanas, Exatas e Sociais da Universidade do Planalto Catarinense-UNIPLAC. Infarma-Ciências Farmacêuticas. [Internet]. 2015 [cited 2018 Nov 28];27(2):142-8. Available from: http://revistas.cff.org.br/?journal=infarma\&page=article\&op=view\&path\%5B\%5D=756

24. Moretti-Pires RO, Corradi-Webster CM. Adaptation and validation of the Alcohol Use Disorders Identification Test (AUDIT) for a river population in the Brazilian Amazon. Cad Saúde Pública [Internet]. 2011 [cited 2018 Nov 03];27(3):497-509. Available from: http://dx.doi.org/10.1590/ S0102-311X2011000300010

25. Ferreira PL, Quintal C, Lopes I, Taveira N. Nicotine control test: Linguistic and psychometric validation of the Fagerström Test. Rev Port Saude Pub [Internet]. 2009 [cited 2018 Dec 02];27(2):37-56. Available from: http://www.scielo.mec.pt/scielo.php?script=sci_arttext\&pid=S0870-90252009000200005\&lng=pt

26. Lima Osório F, Vilela Mendes A, Crippa JA, Loureiro SR. Study of the discriminative validity of the PHQ-9 and PHQ-2 in a sample of Brazilian women in the context of primary health care. Perspect Psychiatr Care [Internet]. 2009 [cited 2018 Dec 01];45(3):216-27. Available from: http:// onlinelibrary.wiley.com/doi/10.1111/j.1744-6163.2009.00224.x/full 
27. World Health Organization -WHO. Physical status: the use and interpretation of anthropometry. Report of a WHO Expert Committee. WHOTechnical Report Series 854. Geneva:World Health Organization; 1995. Available from: http://www.unu.edu/unupress/food/FNBv27n4_sup pl_2_final.pdf

28. National Institute on Alcohol and Alcoholism. Helping patients who drink too much: a clinician's guide, National Institute on Alcohol and Alcoholism: NIAAA 2005 [Internet]. 2005 [cited 2018 Nov 18]. Available from: https://pubs.niaaa.nih.gov/publications/Practitioner/ CliniciansGuide2005/guide.pdf

29. Meneses-Gaya C, Zuardi AW, Loureiro SR, Hallak JE, Trzesniak C, Azevedo MJM,et al. Is the full version of the AUDIT really necessary? Study of the validity and internal construct of its abbreviated versions. Alcohol Clin Exp Res [Internet]. 2010 [cited 2017 Nov 11];34(8),1417-24. Available from: https://doi.org/10.1111/j.1530-0277.2010.01225.x

30. Kroenke K, Spitzer RL, Williams JB. The Patient Health Questionnaire-2: validity of a two-item depression screener. Med Care [Internet]. 2003 [cited 2018 Dec 02];41(11):1284-92. Available from: https://journals.Iww.com/lww-medicalcare/Abstract/2003/11000/ The_Patient_Health_Questionnaire_2_Validity_of_a.8.aspx

31. Le VT, Norris Turner A, Mc Daniel A, Hale KM, Athas C, Kwiek NC. Nonmedical use of over-the-counter medications is significantly associated with nonmedical use of prescription drugs among university students. J Am Coll Health [Internet]. 2018. [cited 2018 Dec 01];66(1):1-8. Available from: https://www.ncbi.nlm.nih.gov/pubmed/28812451

32. Benson K, Flory K. Symptoms of depression and ADHD in relation to stimulant medication misuse among college students. Subst Use Misuse [Internet]. 2017. [cited 2018 Dec 30];52(14):1937-45. Available from: https://www.ncbi.nlm.nih.gov/pubmed/28753050

33. Junqueira MAB, Ferreira MCM, Soares GT, Brito IE, Pires PLS, Santos MA, Pillon SC. Alcohol use and health behavior among nursing professionals. Rev Esc Enferm USP [Internet]. 2017. [cited 2018 Nov 28];51:e03265. Available form: http://www.scielo.br/pdf/reeusp/v51/ en_0080-6234-reeusp-S1980-220X2016046103265.pdf

34. National Institute on Drug Abuse (NIDA). Misuse of prescription drugs: what is the of prescription drug misuse? [Internet]. 2018 [cited 2018 Dec 2]. 37p. Available from: https://d14rmgtrwzf5a.cloudfront.net/sites/default/files/2609-misuse-of-prescription-drugs.pdf

35. Gama ASM, Oliveira MR, Beazussi KM, Gama ASM. Automedicação entre acadêmicos de enfermagem em uma instituição de ensino particular. Rev Científ Interdisciplinar [Internet]. 2016. [cited 2018 Dec 01];3(2):74-84. Available from: http://revista.srvroot.com/ linkscienceplace/index.php/linkscienceplace/article/view/242/145

36. Soares MH, Luís MAV, Corradi-Webster CM, Martins JT, Hirata AGP. Psychological concept of optimism and drug use among nursing students. Acta Paul Enferm [Internet]. 2011 [cited 2019 Jun 05];24(3):393-399. Available from: http://www.scielo.br/pdf/ape/v24n3/en_14.pdf

37. Kudlacek O, Hofmaier T, Luf A, Mayer FP, Stockner T, Nagy C, Holy M, Freissmuth M, Schimid R, Sitte, HH. Cocaine Adulterants and Effects on Monoamine Transporters. In: Preedy VR, editor, The Neuroscience of Cocaine: Mechanisms and Treatment. London: Academic Press; 2017. p. 59-68.

38. Barkla XM, McArdle PA, Newbury-Birch D. Are there any potentially dangerous pharmacological effects of combining ADHD medication with alcohol and drugs of abuse? a systematic review of the literature. BMC Psychiatry [Internet]. 2015 [cited 2018 Nov 13];15(1):270. Available from: https://bmcpsychiatry.biomedcentral.com/articles/10.1186/s12888-015-0657-9

39. Konflanz KL, Silva JM, Dallagnol BG. Uso de anfetamínicos e de anorexígenos por estudantes no município de Santo Ângelo-RS. Saúde (Santa Maria) [Internet]. 2014 [cited 2018 Dec 27];40(2):81-6. Available from: https://periodicos.ufsm.br/revistasaude/article/view/11104

40. Carlini EA. Centro Brasileiro de Informação sobre Drogas Psicotrópicas: UNIFESP Universidade Federal de São Paulo. II Levantamento domiciliar sobre o uso de drogas psicotrópicas no Brasil: estudo envolvendo as 108 maiores cidades do país [Internet]. 2006[cited 2018 Nov 20]. Available from: http://www.cebrid.com.br/wp-content/uploads/2014/10/II-Levantamento-Domiciliar-sobre-o-Uso-de-DrogasPsicotr\%C3\%B3picas-no-Brasil.pdf

41. Quattrin R, Zanini A, Zamolo E, Brusaferro, S. Are Italian nursing students healthy and having protective lifestyle behaviours? a pilot study. Ann Ig [Internet]. 2010 [cited 2018 Dec 06];22(1):83-88. Available from: http://europepmc.org/abstract/med/20476666

42. Paredes NP, Miasso Al, Tirapelli CR. Consumption of benzodiazepines without prescription among first-year nursing students at the University of Guayaquil, school of nursing, Ecuador. Rev Latino-Am Enfermagem [Internet]. 2008 [cited 2018 Nov 30];16(spec):634-9. Available from: https://www.ncbi.nlm.nih.gov/pubmed/18709287

43. Magalhães AEC, Dinelly CMN, Oliveira MAS. Psicotrópicos: perfil de prescrições de benzodiazepínicos, antidepressivos e anorexígenos a partir de uma revisão sistemática. Eletronic J Pharmacy [Internent]. 2016 [cited 2018 Dec 03];13(3):111-22. Available from: https://revistas. ufg.br/REF/article/view/35226/pdf

44. Plotnikoff RC, Costigan SA, Williams RL, Hutchesson MJ, Kennedy SG, Robards SL, Germov J. Effectiveness of interventions targeting physical activity, nutrition and healthy weight for university and college students: a systematic review and meta-analysis. Int J Behav Nutr Phys Act [Internet]. 2015 [cited 2018 Dec 04];12(1). Available from: https://www.ncbi.nlm.nih.gov/pubmed/25890337

45. Deliens T, Deforche B, De Bourdeaudhuij I, Clarys P. Determinants of physical activity and sedentary behaviour in university students: a qualitative study using focus group discussions. BMC Public Health [Internet]. 2015 [cited 2018 Dec 01];15(1):201. Available from: https:// bmcpublichealth.biomedcentral.com/articles/10.1186/s12889-015-1553-4

46. Sousa TF, José HPM, Barbosa AR. Condutas negativas à saúde em estudantes universitários brasileiros. Ciênc Saúde Colet [Internet]. 2013 [cited 2018 Dec 04];18(12):3563-75. Available from: http://www.scielo.br/pdf/csc/v18n12/a13v18n12.pdf

47. Ministério da Educação (BR). Resolução CNE/CES n³ do Conselho Nacional de Educação, de 7 de novembro de 2001 (BR) [Internet]. Diretrizes Curriculares Nacionais do Curso de Graduação em Enfermagem, Brasília (DF). Ministério da Educação. 7 de nov de 2001 [cited 2018 Nov 04]. Available from: http://portal.mec.gov.br/cne/arquivos/pdf/CES03.pdf 